\title{
Abnormal Audit Fees and Stock Price Synchronicity: Iranian Evidence
}

\author{
Mikaeil Mansouri Serenjianeh \\ Accounting Department, University of Kurdistan, Kurdistan, Iran \\ E-mail: mmansouri64@yahoo.com
}

\author{
Nasrollah Takhtaei ${ }^{1}$ \\ Accounting Department, Dezful Branch, Islamic Azad University, Dezful, Iran \\ E-mail: nasrollah_takhtaei@yahoo.com
}

Received: August 16, 2013 Accepted: October 3, 2013 Published: December 1, 2013

doi:10.5296/ajfa.v5i2.4132 URL: http://dx.doi.org/10.5296/ajfa.v5i2.4132

\begin{abstract}
The main objective of this research is to investigate the association between stock price synchronicity. Stock price synchronicity as a criterion for stock market reaction has been the subject of this study for the first time in Iran. For fulfilling the objectives of this research, the post event research method has been applied and for testing the hypothesis the data panel method has been employed. This research sample encompasses 71 accepted firms in Tehran stock market from 2006 to 2010. The results of this research indicate that stock market reaction positively to abnormal audit fees. In other words, the investors tend to assume that abnormal audit fees lead to more information of firm into stock prices and this will enhance audit quality.
\end{abstract}

Keywords: Abnormal audit fees, Actual audit fees, Auditor independence, Normal audit fees, Stock price synchronicity

\footnotetext{
${ }^{1}$. Correspondence author: PhD student in accounting, Department of Commerce, Delhi School of Economics, University of Delhi (India)
} 


\section{Introduction}

With increasing of resource accessible to management, number of stakeholders of firm is also increasing simultaneously that consequence of this situation is an occurrence of conflicts of interest. As a result, stakeholders to align their interests with others or to minimize the impacts of interest's conflict should endure the agency costs. The manager has been in the focus of this conflict is trying to reduce these costs with providing financial information. However due to power of management, independent auditor's professional judgment has been suggested to monitor the performance of management. In order to use audit services, fees should be paid to auditors which is determined by auditors based on their assessment from the audit risk and volume.

In this study, theoretically, actual audit fee comprises two components; (1) standard audit fee, (2) abnormal audit fee. Standard audit fee reflects the effort and costs of litigation risk and actual audit fee is equally fees paid to auditors.

The auditor's efforts might increase with increasing fee payment that leads to quality high in auditing. As a result, market indicates a positive reaction to the high quality of information. Instead, it is possible, auditors' high fees, make them economically to depend on their clients. Such dependence leads to the lack of auditor independence. Therefore, clients do not rely on firm's information that consequences of such procedure leads to a negative market reaction in relation to poor information quality. In this study, stock price synchronicity reflects the contact of company information (audited financial statements) with stock price which considering as a benchmark of market reaction. Whatever stock price synchronicity is increased, the association between company information and stock price is decreased and leads to a negative reaction of stock market. Conversely, with lower stock price synchronicity, relationship between company information and stock price increases and hence market reaction come to be positive.

This study is to examine whether investors perception of an auditor's independence incentives affects the incorporation of firm-specific information into its clients stock prices through two methods. One very likely method using which auditor independence impacts stock price synchronicity is the quality of audited earnings.

Higher (lower) earnings quality is associated with lower (higher) stock price synchronicity. It is consistent with that high quality public information could lead to lower cost of private information (Grossman \& Stiglitz, 1980). Thus high quality public information would encourage informed investors to collect private information and/or would encourage market intermediaries to process public available information into value-relevant private information. As a consequence of more informed trading, stock price are more informed. Also, Kim and Verrecchia (1994) support the view that high quality public disclosure can lead to an increase in trading and more information incorporated into stock prices. They argue that information provided from public disclosure may lead to different interpretation of a firm's performance. Thus, market participants with informed judgments or opinions about a firm's performance are willing to bear the cost for engaging in trading on their judgment. The trading activities incorporate firm-specific information into stock prices. That is, in a market with many risky 
stock, during any given time interval, information about the fundamental values of some firms might be cheap, while information about the fundamental values of some firms might be dear. Trader, ceteris paribus, obtains more private information about the former and less about the latter. Consequently, the stock price of the former, moving in response to informed trading, are both more active and more informative than the stock prices of the latter (Art Durnev, Morck, \& Yeung, 2004).

Another method through which auditor independence affects price synchronicity is that auditor independence affects client firm's transparency. As argued by Jin and Myers (2006), hiring a credible auditing team might be a pre-commitment to convey inside information because; credible auditing may also enhance investors property right by reducing costs of monitoring and controlling the firm. Jin and Myers (2006) develop an analytical model to link firm opaqueness (i.e. lack of transparency) and stock price synchronicity. Their analytical model assumes that insiders (e.g. managers) observe more about the firm-specific information than outside investors, which results in the information asymmetry between insiders and outsider. This information asymmetry (i.e. lack of complete transparency) enables insider to capture more (less) cash flows if the hidden firm-specific information is positive (negative). That is, insiders are required to absorb firm-specific risk and this leads to lower firm-specific risk absorbed by investors. The lower firm-specific risk shared by investors due to the lack of transparency increases the ratio of market to total risk, which means that stock prices move in a more synchronized manner with the market, i.e. stick price synchronicity. Thus, market perception of auditor independence affects the stock price synchronicity through the methods of quality of audited earnings and transparency. By using the relationship between abnormal audit fees and auditor independence, the question that can be begged is that whether the company's information will provide a basis for evaluating the stock price or not.

\section{Hypothesis Development}

If investors realize that this abnormal audit fees is the result of auditors' economic dependence to their employers, auditor independence is lost and the quality of financial reporting is reduced; therefore, investors do not be sure of company information. Consequently, the company's information cannot support the company's stock price in the market. However, if investors believe the abnormal audit fee is due to other factors, apart from economic dependence, and also they believe that abnormal audit fees resulting from removing their reputation and uncertainty assessment, so it increases their efforts, they can use company's information to evaluate the company's stock. In this study, based on the various factors in the perspective of investors in Iran, it is expected that the increase in fees consider due to extraordinary auditors' efforts. Therefore, the following hypotheses are raised:

Main hypothesis: stock market against abnormal audit fees reacts.

Hypothesis 1: The market share against audit fees with a positive sign react positively.

So, in the hypothesis 1 , it is argued that an audit fee in the stock market with positive sign 
indicates a positive reaction. According to the hypothesis 1 , a reduction in audit fees reduces the effort, as a result, leading the negative reaction of the stock market to the information provided. Therefore,

Hypothesis 2: The stock market in audit fees a positive sign indicates a positive reaction.

\section{Empirical Procedures}

This study is of the positive accounting research theoretically. Positive research includes a set of methods that not only express observation but also consider the relationship between observed variables. This study also is applicable from the viewpoint of objective.

From the viewpoint of time period, this study is of post-event research. In post-event research, the researcher detects and investigates the relationship between factors and special conditions that exist before or have occurred using studying their results. Therefore, both dependent and independent variables have occurred in the past and based on this description, this study is called empirical research or post-event research.

On the other side, according to the using sample for running methods and research techniques generalizing sample findings to population, this study is considered as an induction research inferentially. It also can be considered as a correlation research because it attempts to approve the existence relationship between dependent and independent variables.

\subsection{Measurements of abnormal audit fees}

Actual audit fees can be decomposed into two components: normal audit fees and abnormal audit fees. Normal fees reflects auditors efforts costs and litigation risk, and are determined by factors that are common across different clients such as client size, client complexity and client-specific risk, while abnormal fees determined by factor that are idiosyncratic to contractual relationships between auditor and their clients, while are actual fees in excess of normal fees and are more likely to capture the economic bonding.

\subsubsection{Measurements of normal audit fees}

According to Simunic (1980), the model of the standard audit fee variable depends on the probability of occurrence losses and bankruptcy. In this study, the risk of loss of client companies through company size, the total assets $(T A)$ of the company, and bankruptcy of clients are tested by the $Z$ test.

In addition, based on previous studies (Ashbaugh, LaFond, \& Mayhew, 2003; Francis, 2006; Frankel, Johnson, \& Nelson, 2002; Palmrose, 1986), if the financial year is not ending to the end of year, dummy variable is used to control for the seasons of non-work in audit. Additionally, the current ratio, quick (acid) asset ratio, and also financial leverage ratio are used to control the risk of firm. The used model in this study is derived from Simunic (1980) model that is defined as follows:

$$
\begin{aligned}
\text { LAFEE }=b_{0}+b_{1} L T A+ & b_{3} \text { CATA }+b_{4} \text { QUICK }+b_{5} \text { DE }+b_{6} \text { BANKRUPTCY } \\
& +b_{7} \text { FOREIGN }+b_{8} \text { YE }+b_{9} L O S S+\varepsilon
\end{aligned}
$$

Where;

$$
\text { LAFEE = natural log of audit fees; }
$$


LTA = natural log of total assets;

CATA = ratio of current assets to total assets;

QUICK= ratio of current assets (less inventories) to current liabilities;

$D E \quad$ = ratio of long term debt to total assets;

$B A N K R U P T C Y$ = bankruptcy of clients are measured by the $\mathrm{Z}$ test;

FOREIGN = proportion of total sales from foreign operations;

$Y E \quad$ = indicator variable, $1=$ if firm's financial year is not ended to March 20);

LOSS = indicator variable, $1=$ loss in current fiscal year, "0" otherwise;

$\varepsilon \quad=$ residuals

\subsection{Measurements of stock price synchronicity (The standard of stock market reaction)}

The stock price synchronicity measures how firm stock returns are closely tied to marked return is. Following prior literature (Art Durnev et al., 2004; Artyom Durnev, Morck, Yeung, \& Zarowin, 2003; Morck, Yeung, \& Yu, 2000), the stock price synchronicity measure is derived from the $R^{2}$ of the following regression:

$$
R_{\mathrm{i}, t}=\beta_{i 0}+\beta_{i 1} R_{m, t}+\varepsilon_{i, t} R_{\mathrm{i}, t}
$$

$R_{\mathrm{i}, t}:$ Monthly return of each firm

$R_{m, t}:$ Market return in the Tehran Stock Market

The stock price synchronicity (SYN) is defined as the following:

$$
S Y N C H_{i, t}=\operatorname{LOG}\left(\frac{R^{2}}{1-R^{2}}\right)
$$

Where $\mathrm{R}^{2}$ is the coefficient of determination from the estimation of the above equation (1).

3.3 The model for examining the association between stick price synchronicity (The standard of stock market reaction) and abnormal audit fees

The following model derived from the model of Piotroski and Roulstone (2004) is that the $S Y N C H$ (the standard of stock market reaction) as the dependent variable and $A B F E E$ (abnormal fees) as the independent variable. And also, in this study, $\log N I N D, B I G$ auditor, FIRMAGE and ASSET has been considered as a control variable.

$$
\begin{aligned}
\text { SYANCH }= & b_{0}+b_{1} A B F E E+b_{2} \operatorname{logNIND}+b_{3} \text { QUALITY } \\
& +b_{4} \text { FIRMAGE }+b_{5} \log A S S E T+e
\end{aligned}
$$

SYNCH: The standard of stock market reaction as the dependent variable

ABFEE: abnormal audit fees as the independent variable

LogNIND: as the control variable is defined as the natural logarithm of the number of firms in 
the industry. It is expected that the greater the number of firms in a particular industry, contact information, according to the characteristics of the industry, the stock price increases; thus, this leads to a lower stock price synchronicity (the information of the share price of these companies will be affected more).

QUALITY: this variable as a dummy variable takes 1 if audit firm is of high quality. Quality of the audit firm has determined via website of Iranian Association of Certified Public Accountants (IACPA). This variable as a dummy variable take 1 if the audit firm has is a score of A; otherwise zero. It is expected that receiving high fees by high quality audit firms, leading to lower stock price synchronicity and hence stock price data will be most affected.

FIRMAGE: presence of companies in Tehran Stock Exchange (TSE) by the end year 2010 is defined as a control variable. Information environment of older companies are more reliable and accurate than emerging ones and capital market uses company information rather than alarmist methods to evaluate stock prices over time. Therefore, it is expected that firms with long life relates more the companies' information with their stock price in stock exchange.

LogASSET: Natural logarithm of total assets is defined as a control variable. With increasing the total assets in the financial statements, the financial statements will be of most interest and this leads to lower stock price synchronicity (stock market reaction to company information).

$e$ : residuals for firm $i$ at time $t$,

\section{Empirical Results}

Tables 1 and 2 show the descriptive statistics of the study. According to the table 1, the central indicators such as mean, median, and indicators of dispersion, standard deviation, kurtosis and skewness have been calculated for different variables. If mean is more than median representing that there are big points among data. In these cases, the data distribution is Skewness to right, for instance, the distribution in FIRMAGE is Skewness to right. There is no Skewness to right, just the mean and median values of some variables is close to the distribution that it indicate that variables are symmetric. Almost all other variables except for the mentioned variables, particularly dependent variable, are symmetry relatively. This feature is important because the symmetry is one of the properties of normal distribution. Dependent variable is observed with symmetry and skewness distribution close to the normal distribution (stretching and skewness rate in normal distribution is zero). In table 2, $17.7 \%$ of the data is zero value for $Q U A L I T Y$ and $82.3 \%$ is one value.

Table 1. Descriptive statistics

\begin{tabular}{lccccccc}
\hline VARIABLE & Mean & Median & Std.Dev & Skewness & Kurtosis & Min & Max \\
\hline SYNCH & -1.220 & -1.0724 & 1.01852 & -.769 & .516 & -4.31 & 1.02 \\
ABFEE & .01914 & .00515 & .519731 & -.181 & .467 & -1.988 & 1.790 \\
LogNIND & 1.1373 & 1.1761 & .36300 & -1.414 & 1.692 & .00 & 1.46 \\
FRINAGE & 15.37 & 14.00 & 8.534 & 1.607 & 2.294 & 5 & 45 \\
LogASSET & 5.5497 & 5.5428 & .49803 & .055 & .123 & 4.10 & 6.97 \\
\hline
\end{tabular}


Table 2. Descriptive statistics of dummy variable

\begin{tabular}{l|c|c}
\hline & \multicolumn{2}{|c}{ Quality of Audit Firms } \\
\hline Dichotomous & No. Audit firms with A SCORE & \%Audit firms with A SCORE \\
\hline 0 & 63 & $17.7 \%$ \\
1 & 292 & $82.3 \%$ \\
\hline
\end{tabular}

Table 3 represents the results of the relationship between stock price synchronicity, measure of market reaction, and abnormal audit fees using multivariate regression. Regression analysis shows that the determining factors in stock price synchronicity variables explain $0.257 \%$ of variation of dependent variable.

According to the table 3, it can be noted that the multiple correlation coefficient is equal to 0.257 ( $M R=0.257$ ), and the square of the coefficient of determination is equal to 0.066 . So, the three variables of $A B F E E$ (abnormal audit fees), $\log A S S E T$ (log of total assets) and FIRMAGE (lifetime of the stock) explain the net rate of $0.058 \%$ of the variance in the equations in stock price synchronicity. The other variables by external factors and unknown variances which has not mentioned in this study will be explained. In this model, the most important factors that influence the other factors are the variable abnormal audit fees. T-test of the regression coefficient shows that the coefficient was significant $(\mathrm{P}<0.000)$ and the estimated value of stock price synchronicity is effective (table 5). Therefore, the three variables of $A B F E E, \log A S S E T, F I R M A G E$ have a significant impact on stock price synchronicity, but figure 6 indicates that there is no relationship between the quality of the audit firm and the logarithm of the number of firms in the industry with stock prices. The ANOVA's results in table 4 shows that the calculated level of significance for this statistic is equal to 0.000; it shows a significant regression in $99 \%(\mathrm{P}<0.000)$, the negative relationship between stock price synchronicity and audit fees that represent abnormal stock market reaction is positive. So the main research hypothesis is confirmed. Table 3 is the results of the relationship between stock price synchronicity, measure of market reaction) and abnormal audit fees using multivariate regression. Regression analysis shows that factors that determine the stock price synchronicity variables, among all variables were entered into the regression equation, has explained approximately $0.257 \%$ of the dependent variables - stock price synchronicity. According to table 3, it can be stated that the multiple correlation coefficient is equal to 0.257 (MR=0.257), and the coefficient of determination is equal to 0.066. As a result, the three variables of ABFEE (abnormal fees), $\log A S S E T$ (log of total assets) and FIRMAGE (lifetime of the stock) explain the net rate of $0.058 \%$ of the variance of stock price synchronicity in the equations, and the other variables, external factors and unknown variances that has not mentioned, will be explained.

In this model, the abnormal audit fee has had the most important factor than the others. Table 5 shown T-test of the regression coefficient was significant $(\mathrm{P}<0.000)$ and the estimated value of stock price synchronicity is effective. Therefore, the three variables of $A B F E E, \log A s s e t$, FIRMAGE has a significant impact on stock price synchronicity, by contrast, table 6 shows that the quality of the audit firm and the logarithm of the number of firms in the industry, has 


\section{Macrothink Institute ${ }^{\mathrm{TM}}$}

no relationship with stocks prices synchronicity. The ANOVA in table 4 shows that the significance level for this test was 0.000 and it represents that regression is significant in 99\% $(\mathrm{P}<0.000)$ - the negative relationship between stock price synchronicity and unusual fees audit shows positive reaction in stock market. Thus, the main hypothesis of research is proved.

Table 3. The multivariate regression results of stock price synchronicity

\begin{tabular}{lccccc}
\hline VARIABLE & Coef. & R-squared & Adj R-squared & Std. Err. & Durbin-Watson Stat \\
\hline SYNCH & 0.257 & 0.066 & 0.058 & 0.988 & 1.89 \\
\hline
\end{tabular}

Table 4. ANOVA analysis results of stock price synchronicity

\begin{tabular}{lccccc}
\hline Source & Sum of Squares & df & Mean Square & F-statistic & Sig. \\
\hline Model & 24.244 & 3 & 8.081 & 8.272 & 0.000 \\
Residual & 342.922 & 351 & 0.977 & & \\
\hline Total & 367.166 & 354 & & & \\
\hline
\end{tabular}

Table 5. Independent variables coefficients that remain in model

\begin{tabular}{l|c|c|c|cc}
\hline \multirow{2}{*}{ VARIABLE } & \multicolumn{2}{|l|}{ Unstandardized Coefficients } & Standardized Coefficients & \multirow{2}{*}{ t-statistic } & Sig. \\
\cline { 2 - 4 } & $\mathrm{B}$ & Std.B & Beta & & \\
\hline CONCEPT & 0.322 & 0.603 & - & 0.535 & 0.593 \\
ABFEE & -0.32 & 0.107 & -0.155 & -3.007 & 0.003 \\
LogASSET & -0.319 & 0.106 & -0.155 & -3.000 & 0.003 \\
FIRMAGE & 0.016 & 0.006 & 0.132 & 2.563 & 0.011 \\
\hline
\end{tabular}

Table 6. Statistic relating independent variables excluding from final model

\begin{tabular}{lcccc}
\hline VARIABLE & Beta & t-statistic & Sig. & Partial correlation \\
\hline ABFEE & 0.007 & 0.183 & 0856 & 0.024 \\
LogNIND & -0.011 & -0.279 & 0781 & -0.036 \\
\hline
\end{tabular}

The results in table 7 show a positive relationship between stock price synchronicity with abnormal audit fees. According to this table, it can be stated that the correlation coefficient is $0.146(\mathrm{R}=0.146)$. The coefficient is 0.021 which 0.015 percent of the value of that stock price synchronicity in abnormal audit fees is associated with positive symptoms and the rest depends on other factors. Adjusted coefficient of determination in this case is equal to 0.021 percent. According to Watson Statistic, 2.5 to 1.5, the remaining independent can be concluded. In table 8 the significance of the regression is calculated using $\mathrm{F}$ test. The ANOVA shows that there is a significant difference in this statistic $(\mathrm{P}<0.000)$ and it means a significant relationship in regression $(\mathrm{P}<0.000)$. Table 9 indicates that with increase of a unit in audit fees abnormal with positive sign, - 0.146 of unit synchronous stock price will drop.

T-test of the regression coefficients in this table shows that a significant relationship $(\mathrm{P}<0.000)$ and the estimated value of stock price synchronicity is effective. Based on these results, it is 


\section{Macrothink}

Asian Journal of Finance \& Accounting

ISSN 1946-052X

2013, Vol. 5, No. 2

stated that abnormal audit fees, with signs positive, impact on stock price synchronicity negative relationship between stock price synchronicity and abnormal audit fees with positive sign indicates a positive reaction in the stock market. Therefore, sub-hypothesis 1 is confirmed.

Table 7. The regression results of stock price synchronicity on audit fees abnormal with positive sign

\begin{tabular}{lccccc}
\hline VARIABLE & Coef. & R-squared & Adj R-squared & Std. Err. & Durbin-Watson Stat \\
\hline ABFEE & 0.146 & 0.021 & 0.015 & 1.06 & 1.8 \\
\hline
\end{tabular}

Table 8. ANOVA analysis results of stock price synchronicity and audit fees abnormal with positive sign

\begin{tabular}{lccccc}
\hline Source & Sum of Squares & df & Mean Square & F-statistic & Sig. \\
\hline Model & 4.029 & 1 & 4.029 & 3.572 & 0.04 \\
Residual & 183.869 & 163 & 1.128 & & \\
\hline Total & 187.898 & 164 & & & \\
\hline
\end{tabular}

Table 9. The regression results of effects of audit fees abnormal with positive sign on stock price synchronicity (dependent variable)

\begin{tabular}{l|c|c|c|cc}
\hline \multirow{2}{*}{ SYNCH } & \multicolumn{2}{|c|}{ Unstandardized Coefficients } & Standardized Coefficients & \multirow{2}{*}{ t-statistic } & Sig. \\
\cline { 2 - 4 } & $\mathrm{B}$ & Std.B & Beta & & \\
\hline CONCEPT & -1.06 & 0.157 & - & -6.762 & 0.000 \\
ABFEE & -0.585 & 0.310 & -0.146 & -1.890 & 0.04 \\
\hline
\end{tabular}

According to the table 10, it can be stated that the correlation coefficient is equal to 0.119 $(R=0.119)$. The coefficient of determination obtained 0.014 ; it shows that 0.014 percent of changes in stock price synchronicity are related to abnormal audit fees, with negative sign, and the rest depends on other factors. Adjusted coefficient of determination in this case is equal to 0.009 percent. Due to the amount of Watson Statistic is between 1.5 and 2.5; the remaining independent can be concluded. According to the table 11, the ANOVA show a significant variance for this test which is equal to 0.111, indicating that the regression is not significant. So, it can be announced that abnormal audit fees are not significantly and negatively affect the stock price synchronicity; consequently, sub-hypothesis (2) is rejected.

Table 10. The regression results of stock price synchronicity and audit fees abnormal with negative sign

\begin{tabular}{lccccc}
\hline VARIABLE & Coef. & R-squared & Adj R-squared & Std. Err. & Durbin-Watson Stat \\
\hline ABFEE & 0.119 & 0.014 & 0.009 & 0.98 & 1.92 \\
\hline
\end{tabular}


Table 11. ANOVA analysis results of stock price synchronicity and audit fees abnormal with negative sign

\begin{tabular}{lccccc}
\hline Source & Sum of Squares & df & Mean Square & F-statistic & Sig. \\
\hline Model & 2.486 & 1 & 2.486 & 2.561 & .111 \\
Residual & 172.792 & 178 & 0.971 & & \\
\hline Total & 175.279 & 179 & & & \\
\hline
\end{tabular}

Table 12. The regression results of effects of audit fees abnormal with negative sign on stock price synchronicity

\begin{tabular}{|c|c|c|c|c|c|}
\hline \multirow{2}{*}{$S Y N C H$} & \multicolumn{2}{|c|}{ Unstandardized Coefficients } & \multirow{2}{*}{$\begin{array}{c}\text { Standardized Coefficients } \\
\text { Beta } \\
\end{array}$} & \multirow{2}{*}{ t-statistic } & \multirow{2}{*}{ Sig. } \\
\hline & $\mathrm{B}$ & Std.B & & & \\
\hline CONCEPT & -1.271 & 0.111 & - & 11.428 & 0.000 \\
\hline ABFEE & -0.328 & 0.205 & -0.119 & -1.6 & 0.111 \\
\hline
\end{tabular}

\section{Summary and Concluding Remarks}

The purpose of this study is to examine the stock market reaction to abnormal audit fees of listed companies in Tehran stock exchange. Stock market reaction to stock price is determined by considering theoretical research, which means lower stock price synchronicity has a positive reaction in stock market and vice versa. Totally, the results show that there is a significant and negative relationship between stock price synchronicity and abnormal audit fees. In other words, the stock market will react positively than abnormal audit fees. In terms of investors and users of financial statements, increase in audit fees leads to more contact information in the stock price. In order to analyze the different results from abnormal audit fees, with positive sign (additional fee real standard) and negative sign (the actual additional fee standardized) and its effect, separately, evaluated on stock price synchronicity. The results showed that there is a negative relationship between stock price synchronicity and auditing fees with positive signs. The results indicate that investors in excess of the fee paid to the auditor's stock price, leading more contact information to stock price; consequently, positive stock market reaction. Also, the study shows that there is no significant relationship between stock price synchronicity and auditing fees. In fact, Investors do not react to payments that are less than actual fees paying to auditors. The results are consistent with Desai, Desai, Singhvi, and Munsif (2012), Srinidhi and Gul (2007), Krishnan, Sami, and Zhang (2005) and Choi, Kim, and Zang (2006). Each of these studies examined the association audit fees with audit quality and financial reporting process. These results suggest a positive association between audit fees and audit quality. On the other hand, the results are not consistent with Wang (2009) results. The study carried out by Wang (2009) examined whether the abnormal audit fee related the company's information to the stock price and the results showed that high audit fees lead to auditor independence; so, it decreases audit quality and increases stock price synchronicity and inconsistent results may be due to investors' perception of the relationship. 


\subsection{Research suggestions}

1. The study, for the first time, investigates the abnormal audit fees and stock price synchronicity in Tehran Stock Exchange (TSE). In future research, the effect of other factors, on each of these variables, can separately be investigated.

2. In this study, only the variables of abnormal audit fees, natural logarithm of the number of firms in the industry, the size of auditing firm, the time spent in the stock market and the natural logarithm of total assets is considered. While many variables, including the ratios of corporate debt, profit, and others in stock price synchronicity are effective; so it is recommended to future researchers to use them.

3. The range of studied years is only from 2006 to 2010, while the use of a longer period of time can give more accurate results.

4. Some of the variables have more than one operational definition that it can be used by other definitions. For example, non-audit fees can be used instead of audit fees - financial advisory, tax, etc.

5. The research can be used in various industries separately or jointly for some industries and according to the nature of industrial activity, different results can be expected.

\section{References}

Ashbaugh, H., LaFond, R., \& Mayhew, B. W. (2003). Do nonaudit services compromise auditor independence? Further evidence. The Accounting Review, 78(3), 611-639. http://dx.doi.org/10.2308/accr.2003.78.3.611

Choi, J., Kim, J.-B., \& Zang, Y. (2006). The association between audit quality and abnormal audit fees. Available at SSRN 848067.

Desai, R., Desai, V., Singhvi, M., \& Munsif, V. (2012). Audit Fees, Nonaudit Fees, and Auditor Quality: An Analysis from the Indian Perspective. Journal of Accounting, Ethics and Public Policy, 13(2), 151-165.

Durnev, A., Morck, R., \& Yeung, B. (2004). Value-enhancing capital budgeting and firm-specific stock return variation. The Journal of Finance, 59(1), 65-105. http://dx.doi.org/10.1111/j.1540-6261.2004.00627.x

Durnev, A., Morck, R., Yeung, B., \& Zarowin, P. (2003). Does Greater Firm-Specific Return Variation Mean More or Less Informed Stock Pricing? Journal of Accounting Research, 41(5), 797-836. http://dx.doi.org/10.1046/j.1475-679X.2003.00124.x

Francis, J. R. (2006). Are Auditors Compromised by Nonaudit Services? Assessing the Evidence*. Contemporary Accounting Research, 23(3), 747-760. http://dx.doi.org/10.1506/4VD9-AE3K-XV7L-XT07

Frankel, R., Johnson, M., \& Nelson, K. (2002). The relationship between audit fees for nonaudit services and earnings quality. The Accounting Review, 77(4), 71-105. http://dx.doi.org/10.2308/accr.2002.77.s-1.71 
Grossman, S. J., \& Stiglitz, J. E. (1980). On the impossibility of informationally efficient markets. The American economic review, 70(3), 393-408.

Jin, L., \& Myers, S. C. (2006). R^2 around the world: New theory and new tests. Journal of Financial Economics, 79(2), 257-292. http://dx.doi.org/10.1016/j.jfineco.2004.11.003

Kim, O., \& Verrecchia, R. E. (1994). Market liquidity and volume around earnings announcements. Journal of Accounting and Economics, 17(1), 41-67. http://dx.doi.org/10.1016/0165-4101(94)90004-3

Krishnan, J., Sami, H., \& Zhang, Y. (2005). Does the provision of nonaudit services affect investor perceptions of auditor independence? AUDITING: A Journal of Practice \& Theory, 24(2), 111-135.

Morck, R., Yeung, B., \& Yu, W. (2000). The information content of stock markets: why do emerging markets have synchronous stock price movements? Journal of Financial Economics, 58(1), 215-260. http://dx.doi.org/10.1016/S0304-405X(00)00071-4

Palmrose, Z.-V. (1986). The effect of nonaudit services on the pricing of audit services: Further evidence. Journal of Accounting Research, 24(2), 405-411. http://dx.doi.org/10.2307/2491144

Piotroski, J. D., \& Roulstone, D. T. (2004). The influence of analysts, institutional investors, and insiders on the incorporation of market, industry, and firm-specific information into stock prices. The Accounting Review, 79(4), 1119-1151. http://dx.doi.org/10.2308/accr.2004.79.4.1119

Simunic, D. A. (1980). The pricing of audit services: Theory and evidence. Journal of Accounting Research, 18(1), 161-190. http://dx.doi.org/10.2307/2490397

Srinidhi, B., \& Gul, F. A. (2007). The differential effects of auditors' non-audit and audit fees on accrual quality. Contemporary Accounting Research, 24(2), 595-629. http://dx.doi.org/10.1506/ARJ4-20P3-201K-3752

Wang, X. (2009). Do Abnormal Audit Fees/non-audit Fees Communicate Firm Specific Information to the Stock Market? (PhD Thesis), School of Accounting and Finance, The Hong Kong Polytechnic University. 